logos_i_ethos_2017_1_(44), s. 47-70

DOI: http://dx.doi.org/10.15633/lie.2121

\author{
Balázs M. Mezei \\ Pázmány Péter Catholic University
}

\title{
Realist Phenomenology and Philosophy of Religion. A Critical Reflection ${ }^{1}$
}

\section{Introduction: The Importance of Philosophy of Religion}

The importance of philosophy of religion in contemporary discussions is both manifold and simple. It is manifold, because 'religion' is a complex phenomenon with a long history and a future open to often unforeseeable developments. Even in the context of secularization we see that the old notion of religion finds surprisingly new forms of appearance, forms which influence contemporary society, culture, and politics. ${ }^{2}$ And the importance of philosophy of religion is simple,
Balázs M. Mezei - Professor of Philosophy at Pázmány Péter Catholic University, Hungary. He published more than 30 books and 150 scholarly articles on philosophy of religion, phenomenology, political and literary criticism. He organized master and doctoral programs at his home university. He was a visiting scholar at the University of Notre Dame, Georgetown University, Loyola University in Maryland, the Institute for Human Sciences in Vienna, the Husserl Archives in Leuven, the Kirk Center for Cultural Renewal, and other institutions. He is vice-president of the Hungarian Society for the Study of Religion. He has been a Senior Fulbright Fellow at the University of Notre Dame in 2015. He published Religion and Revelation after Auschwitz (Bloomsbury, 2013); he authored Illuminating Faith and Christian Wisdom Meets Modernity (both with Francesca Murphy and Kenneth Oakes, 2015 and 2016). His Radical Revelation: A Philosophical Approach is forthcoming with Bloomsbury in 2017. Currently, he is editor-in-chief of The Oxford Handbook of Divine Revelation.

1 An earlier version of this text was presented at the international conference organized in honor of Prof. Josef Seifert in 2015 in Granada, Spain. The present text contains some important modifications missing in the earlier one.

2 Cf. Charles Taylor's views on the importance of some form of religiousness in his monumental A Secular Age of 2007. See also his lecture Master Narratives of Modernity (delivered on October 21, 2008) the same subject matter available here: https://www.youtube.com/watch?v=m95ck7A2Ooc 
because the simple fact in religion is the self-revelation of the totally different and its relation to us. ${ }^{3}$ Philosophy, properly speaking, has always been the endeavor to conceive the totally different or perhaps even to conceive the impossibility of such a conception. Yet such an understanding of impossibility is the richest source of philosophical reflection.

In what follows I will focus on the importance of Catholic philosophy, that is, the specifically Catholic approach to the fundamental reality of religion. I shall also offer a list of models describing the possible relationships between Catholicism and philosophy. I identify the unity model as a model connected to phenomenological realism; and I will detail the important contribution of Josef Seifert to such a phenomenological realism.

\section{Catholicism and Philosophy}

Historically, philosophy has always been an important part of Catholicism; in some periods it played a more, in others a less important role. The critical rejection of a certain understanding of philosophy, present in one verse of the New Testament ( $\mathrm{Col} \mathrm{2:8)},{ }^{4}$ is compensated by other loci where Greek philosophy is put into a favorable light. Such is, for instance, St. Paul's sermon to the philosophers on the Areopagus. His most famous sentence is this:

For in him we live, and move, and have our being; as certain also of your own poets have said, for we are also his offspring. (Acts 17:28)

This notion expresses a philosophical theology related to Platonism and Stoicism; and even the mention of the resurrection of the dead in Acts 17:31 recalls Plato's 'Phoenician story' about human beings nurtured

3 Cf. B. M. Mezei, Religion and Revelation after Auschwitz, New York 2013, Part 2.

4 The important elements of this 'philosophy' are 'vain deceit,' 'the tradition of men,' 'the rudiments of the world,' and the denial of Christ. Yet philosophy is not forced to be deceitful, follow some narrow traditions, be empirically oriented, and need not deny the crucial importance of Christianity. 
in the womb of the earth and born of it when their time is come. ${ }^{5}$ Clement of Alexandria, nevertheless, did not find many followers with his view that philosophy, and not only the Old Testament, was a lodestar ('paidagogos') leading mankind to Christ. The early Fathers certainly knew Greek philosophy well and used its results in many ways, but refused to attribute to it a sacramental role similar to the Old Testament writings. Still, most of the central terms of Patristic theology remain incomprehensible without a sufficient knowledge of then contemporary philosophical discussions. Philosophy, especially Middle and Late Platonism was indeed the background of the language, culture, and general philosophical orientation of the Fathers. ${ }^{6}$

Many of the Patristic writings indicate, nevertheless, that their authors were not familiar with the sources of Greek philosophy as we know these sources today. For instance, St. Augustine's criticism of 'philosophy', especially Platonism, shows that the judgment of the holy bishop was not based on the study of original texts but rather on popular summaries; still, a genius like St. Augustine could grasp the important points which he did not only criticize but, in some respects, praised as well. What escaped his attention escaped the attention of many till today: namely the fact that philosophy in its popular forms was merely a façade of a deeper knowledge, a closed tradition of universal vision originating in Hellenistic syncretism.

In this perspective, philosophy was seen as "a gift from the gods to the mortal race whose value neither has been nor ever will be surpassed."7 Christian theology divided this 'gift from the gods' into theology as the

5 Plato, Republic $414 \mathrm{c}-\mathrm{e}$, in: Plato, The Complete Works, ed. J. M. Cooper, IndianapolisCambridge1997, p. 1050.

${ }^{6}$ Cf. Gal 3:24; Clement of Alexandria, Stromata, in: The Ante-Nicene Fathers, New York 1913, p. 305.

7 Plato, Timaeus 47 b, in: Plato, The Complete Works, op. cit., p. 1250. Characteristically, this metaphorical description of philosophy as a 'gift' (á $\gamma a \theta$ óv) figures in a text which describes the Ptolemaic cosmos in a theologically meaningful way, in a way I termed 'cosmo-theological' (B. M. Mezei, Religion and Revelation after Auschwitz, New York 2013, p. 34 sq.), thereby making obvious the close connection of philosophy to the intricate experience of the universe by ancient humanity. See also my piece Demythologizing Christian Philosophy: An Outline, "Logos i Ethos" 2013 nr 2 (35), p. 109-146. 
doctrine of divine gift per se; and into philosophy as the natural way of the human mind to prepare itself for the divine gift of theology. The Christian notion was thus in more than one way an organic enlargement of the earlier understanding of the importance of philosophy.

Following the Protestant historical criticism of the nineteenth century, Patristic Christianity was seen for a long time as a synthesis of Hellenism and Judaism on the basis of spiritual movements related to the Gospel. Underlying this idea there is the presupposition that Hellenism and Judaism constitute historical and cultural antipodes. A synthesis of Hellenism and Mosaic faith, accordingly, had to be a strained endeavor. Nevertheless, such a sharp opposition between Old Testament faith and Hellenism is an exaggeration; the process of the unification of the Old Testament faith cannot be considered isolated from the general cultural processes of the neighboring peoples living around the Mediterraneum. The more we approach the beginning of our epoch, the less such a sharp separation appears realistic. From our perspective today, it is not the difference that is striking between religious forms of those times, but rather their close similarity.

Pope Benedict XVI, therefore, rightly calls our attention to the importance Hellenism played in the formation of Christianity. ${ }^{8}$ If philosophy is considered the highest intellectual expression of Hellenism - and I have in mind especially the Platonic corpus as inherited from the school of Thrasyllus of Alexandria - then philosophy indeed contributed to the emergence of the intellectual building of Christianity during the first six centuries. Catholicism is not popular Platonism, as for instance Franz Brentano believed, but Catholicism used in many ways the Platonic understanding of reality in the shaping of its doctrinal, moral, and liturgical contents. St. Augustine's theological understanding is clearly influenced not only by mystical experiences, but also by the Neo-Platonism of his intellectual circles. Augustinianism has been the most important vehicle of transmitting Platonic and Neo-Platonic influences in the West: Duns Scotus, Bonaventure, Malebranche, Fénelon, or - to mention a more

8 Cf. Benedict XIV, Pope, Apostolic Journey of His Holiness Benedict XVI to München, Altötting and Regensburg (September 9-14, 2006); see also the bibliography at the end of this text. 
recent example - Eric Przywara are excellent representatives of this claim. Classical phenomenology was seen already at the turn of the last century as a revival of Platonic and Augustinian thought. ${ }^{9}$

Platonism characterized the first millennium of the history of the church; in a similar way, St. Thomas Aquinas' reception of the thought of Aristotle had a lasting influence on the second millennium. Thomas needed to have not only the talent of a philosophical and theological genius to work out his summae, but an intellectual courage as well. Thomas was aware of the opposition of traditionalist theologians who found the then new Aristotelian rationalism threatening to the integrity of faith. Still, Thomas kept working on his great contributions which synthesized Augustinian Platonism, Dionysian theology, and Aristotelian science. Aristotelianism, as it were, was the Zeitgeist of the thirteenth century; Thomas Aquinas responded to the new interest with his great works.

Besides his personal and philosophical courage, it is centrally important to see that Thomas Aquinas was able to create a synthesis of divergent traditions. In a certain way, Thomas incorporated Aristotelian science into Christianity; in another way, however, he synthesized the authority of Pseudo-Dionysius with the freedom of the questioning mind. He did not only summarize points of view and did not only formulate the Christian standpoint but fundamentally contributed to a new understanding of reality, personhood, and God with his theological and philosophical solutions. By creating such intellectual masterpieces, Thomas contributed to the emergence of the West as an autonomous cultural power.

In the historical evolution of the relationship between Catholicism and philosophy, some important improvements have to be mentioned. Renaissance Platonism contributed to the diminishing of the grasp of Aristotelian science on theology and prepared the way to Protestant Reformation in which Augustinianism had an important role to play. The influence of Platonism was mirrored in the new, mathematicalgeometrical ideal of philosophy which came to the fore especially in the works of Descartes and his followers. Rationalism in general, however, 
proved to be a closer ally of intellectual Catholicism than it initially appeared, for it was intimately related to the scientific mind of an Aristotelian understanding of reality. The theological rationalism of the seventeenth and eighteenth centuries was at the same time abstractly Platonic and analytically Aristotelian.

Catholic Romanticism, in which Clemens Brentano (the uncle of Franz Brentano) played a crucial role, was the appropriate framework in which some of the achievements of the new German philosophers could have been integrated. Kant and his most important followers attempted to overcome the difficulties caused by skepticism and dogmatism in philosophy. They hoped to be able to contribute to a new understanding of faith as well. Even Kant himself wished to make place for faith - while destroying fundamental pillars of a locally empirical view of reality. German idealism, nevertheless, influenced Catholic philosophy in a number of ways, so much so that some decades later new patterns of the relationship between philosophy and Catholicism became possible especially in the works of the theologians belonging to the Catholic Tübingen School (such as Johann Sebastian von Drey or Johann Adam Möhler). In such patterns, a strong criticism of a number of views of the German idealists was counterbalanced by the use of their other views for the benefit of a new philosophical understanding of Catholic Christianity.

Many of the important Catholic thinkers of the twentieth century from Max Scheler and Dietrich von Hildebrand to Joseph Maréchal, Karl Rahner and Hans Urs von Balthasar - not only criticized certain tenets of German idealism, but used important insights of the same current to develop a new form of philosophical Catholicism. ${ }^{10}$ In these developments, the relationship between philosophy and Catholicism was again revitalized and elaborated into new and synthetic forms of thinking. The general

10 In fact, many of the prominent German theologians today, from Hans Küng through Johann Baptist Metz to Pope Benedict XVI, show not only an intimate knowledge of the great German philosophers from Leibniz and Kant to Heidegger, Gadamer and Habermas, but also a deep understanding of the theological and philosophical significance of the problems and methods these authors addressed and used. Just as St. John Paul II, Benedict XVI is well-versed in German philosophy which is shown in many of his writings. 
thesis of this historical summary - forced on the basis of the latest development of the twentieth and twenty-first centuries. Specific attention is to be given to realist phenomenology which I shall consider below.

The promising rise of Neo-Thomism and Neo-Scholasticism from the second half of the nineteenth century created a new impetus in the understanding of the relationship between Catholicism and philosophy. This new philosophy dispensed with the framework of Catholic Romanticism and preferred a more down-to-earth realism. Such a realism, nevertheless, constituted a sharp opposition with the philosophy of the Patristic age, an opposition twentieth century theologians began to realize.

On the other hand, even in the new Catholic realism, a more complex epistemology emerged. Matteo Liberatore for instance contributed not only to the acceptance of Neo-Thomism as the official philosophy of the church but worked out philosophical doctrines influential in his time, such as the notion of the 'direct universal' (universale directum) as distinct from the 'reflected universal' (universale reflexum). According to Liberatore, the direct universal exists in reality and not only in the mind, such as for instance the direct universal of a quidditas or a 'human being.' A direct universal can be intuited and determined without reference to a particular individual, for instance when we directly perceive that a human being is by definition a living being. The notion of the direct universal influenced the emerging philosophies of value, Franz Brentano's notion of 'inner perception' of intentionality, and also the 'categorical intuition' of the early Husserl. ${ }^{11}$

As a consequence of the encyclical letter Aeterni patris of 1879, the most influential Catholic theologians of the twentieth century, and a number of the most important philosophers as well, received and processed the various aspects of Thomism. Even such authors as Heidegger, Wittgenstein, Whitehead, Russell or Sartre showed traces of the Thomistic revival in their works. ${ }^{12}$

11 For more details see Liberatore, Matthaeus, Institutiones philosophicae, Romae 1857, 244 sq.

12 There are many ways one can demonstrate this influence but the best example, in my view, is offered by Eric Przywara whose works show the deep and organic connections between Neo-Thomism and twentieth century philosophy. 
In Catholicism, the decisive importance of Neo-Thomism became counterbalanced by a number of other interests coming to the fore from the 1930s, and especially after the Second Vatican Council. Pope John Paul II's Fides et ratio of 1998 - the second encyclical letter on philosophy ever written by a pope - shows a variety of way as to how the priority of Thomistic thinking can be completed by ideas of German idealism, phenomenology, and existentialism. Fides et ratio goes beyond the horizon of Thomism and opens the way to a new evaluation of the relationship between Catholicism and philosophy.

On the contemporary scene, a philosophy of religion of Catholic orientation has become especially significant. Let me mention just the most influential movements:

- The 'theological turn of French phenomenology' (Dominique Janicaud's expression) which originates in Lévinas' critical response to Heidegger's thought;

- Analytical Thomism or analytical theology, especially the works of US and UK philosophers (Michael Rea or John Haldane);

- The Radical Orthodoxy movement (John Milbank) - there belongs to this movement such ramifications as the anti-Gnostic polemics of Cyril O’Regan;

- We need to mention the world-wide influence of the thought of Josef Seifert, that is, his realist phenomenology. ${ }^{13}$

Before I offer a substantive evaluation of some of these developments, let me outline a theoretical schema.

\section{Models of Relationship}

On the basis of the above summary I offer a list of models of the relationship between Catholicism and philosophy. There are two perspectives

13 Perhaps not comparable to the influence of the schools just mentioned, we still may refer to the work of the Fides et ratio Research Group at Pázmány Péter Catholic University in Hungary which has already arranged a number of successful conferences, takes part in the publication of book series and contributes to important publications by Bloomsbury Academic Press and Oxford University Press. 
in which we can speak of models here: either from the point of view of philosophy, or from that of Catholicism. The list of the models I offer can be understood in both ways.

The models are as follows:

1. The Model of Hidden Presence (philosophy is latent in Catholicism and vice versa);

2. The Model of Supremacy (one of the two factors is considered to be more important than the other one);

3. The Model of Fulfillment (one of the factors is considered as the fulfillment of the other one);

4. The Model of Partnership (the factors form some kind of a correlation);

5. The Model of Challenge (the factors exert a critical function with respect to each other);

6. The Model of Proleptic Significance (either of the two factors is considered in terms of a proleptic significance for the other, that is as representative of insights crucial in the proper functioning of the other factor).

In Model 1 , one of the factors is the determining perspective in which the other factor is envisioned. Philosophy, as historical analysis shows, offered for a long time such a perspective. Greek philosophical terminology was used abundantly in the making of the Christian doctrines. On the other hand, it is often said that a certain philosophical conception is based on its underlying, inexplicit notion of the absolute, God. In such cases, this underlying notion forms the perspective in which philosophy is conceived.

In Model 2, one of the factors, philosophy or Catholicism, is used as a means to reach a certain unity. When philosophy is considered 'the servant of theology, ancilla theologiae, it is Model 2 we apply. Christianity, however, can be used as a means in a philosophical conception, as for instance the notion of the Trinity, or at least some interpretation of it, determines the entire structure of Hegel's thought.

In Model 3, either of the two factors is understood to be the fulfillment of the other. In the traditional conception, philosophy is fulfilled 
in theology, reason in faith, pagan thought and Old Testament preparation in the revelation of Christ. Catholic Christianity considered itself as the fulfillment of the history of humanity, for Jesus Christ arrived at the 'fullness of times.' On the other hand, there are views which claim that Christianity was merely instrumental to a higher level of philosophical awareness, to a new philosophy of rationalism, idealism, existentialism, or some kind of a theological phenomenology.

In Model 4, philosophy and Catholicism are perceived as mutually supporting each other. This can be done either by rejecting to arrange them into a hierarchy or else by emphasizing the many dimensions in which philosophy or theology respectively has a higher importance. As a general principle it is maintained in this model that philosophy and Catholicism are mutually supportive of each other in various fields; thus it is the supporting element that is stressed in their relationship.

Model 5, however, emphasizes the mutual challenges philosophy and theology prepare for each other. Philosophy is seen here as critical of theology, for instance in the works of Hegel or Heidegger; and theology is considered as critical of philosophy, such as in the work of Karl Barth or Hans Urs von Balthasar. This critical view can be conceived in extreme terms as a mutual exclusion. This happens in fideism, or in straightforward atheism, existential atheism, or in some forms of idealism.

Model 6 describes the relationship of the two factors in terms of intrinsic importance for each other. By 'intrinsic importance' I mean the essential contribution without which none of the two factors, philosophy or Catholicism, is capable of performing its proper function. The most important form of such a contribution is the emphasis on the limits of the other factors in a well-defined sense. Thus, Catholicism as the most general form of religious faith and practice calls our attention to the limits of philosophical autonomy in the intellectual and moral senses. On the other hand, philosophy by its analytic and synthetic capabilities is apt to point out the importance of paying appropriate attention to new developments in culture, the sciences, and in the history of societies. Philosophy, in the present sense, is capable of offering a historical criticism of theology not only by pointing out the semantic changes of 
fundamental theological notions, but also by raising the overall question of the meaning of theology as such.

I call this model the model of proleptic significance, since philosophy, thus conceived, is able to point out the importance of the rethinking and restructuring of traditional conceptions in view of the actual changes in our world. Philosophy has a proleptic role in the more natural sense as well that it points to our current developments in the world of culture, society and the sciences, which are becoming important for Catholicism in general and for theology in particular. Philosophy, by fulfilling its proleptic role, identifies the weakening plausibility of theological notions in technological societies and prepares an overall renewal of religion.

On the other hand, Catholicism can play a similarly proleptic role with respect to philosophy. Philosophy has the tendency to conceive of human knowledge as the absolute point of reference in understanding reality. Nevertheless, no form of knowledge is able to escape the circle of presupposing the validity of its mode of knowledge; and thus no philosophy is able to make itself thematic as philosophy in its entirety. Philosophy points beyond itself; or to put it differently, philosophy shows its own heteronomy. Catholicism as a form of religion with faith in its center, or theology in the narrower sense with its emphasis on an ultimately heteronomous realm, can help philosophy to recognize its own limitations. Catholicism can assist philosophy in looking forward to new types of thinking beyond the traditional types of philosophical knowledge, such as the type I identify as a non-standard philosophical theology conceiving and explaining the importance of an apocalyptic phenomenology. ${ }^{14}$

It is almost needless to say that the present overview would not be possible without the perspective of philosophy in itself and in its proleptic significance. Catholicism has never aspired to eliminate the role of philosophy from its realms, while other Christianity-based currents, such as the thought of Karl Barth, rejected any role of philosophy in the structure and content of theology. However, even Barth himself applied

14 See my forthcoming work entitled Radical Revelation: A Philosophical Approach, in which my method is described as a 'non-standard philosophical theology.' 
sophisticated philosophical methods in his writings. Not even an aesthetic detour, such as offered by Hans Urs von Balthasar, can overlook the important role of philosophy in the logical and structural workings of a theological system. A summary analyzing the relationship between faith and reason or Catholicism and philosophy cannot be properly realized if not in the perspective of a philosophical approach - always with due attention to the proleptic role of Catholicism.

\section{The Unity of Models}

Which model shall we accept as an appropriate description of the relationship between philosophy and Catholicism? In some accounts one or the other model is declared to be the only solution. In my view, it is more promising to unify these models into a single one. I term this model the unity model. Philosophy and Catholicism, variously conceived, can be envisioned as being related to one another in terms of perspective, supremacy, fulfillment, partnership, challenge, and proleptic significance. The guiding principle of such unity is that the validity of one model cannot be stretched beyond the limits of the validity of the other models. That is to say, philosophy can be seen as the perspective in which Christianity was conceived in the world of Hellenism, but this does not mean that Christianity did not become the perspective in which philosophy came to understand itself during the centuries of Christianity. The other models can be combined into a single whole in a similar way.

The unity model is that of the dynamic unity of these particular relationships, a dynamism which is simultaneously historical and conceptual, cultural, and scientific. By dynamism I especially mean that, in certain ages, some of the particular relationships come to the fore. In our age I believe that the features of partnership and proleptic significance are particularly important. It is through partnership and proleptic significance that we may have the appropriate view of the unified relationship between Catholicism and philosophy.

The unity model, thus, is present to us in these particular features; which is not to say that I deny the relative importance of the other fea- 
tures. Nevertheless, in earlier ages it was important to stress the point of the general priority of theology over philosophy. While the essential relationship between philosophy and theology do not change, there are periods in which philosophy has a particular significance, such as in the age of the First Scholasticism. Similarly, in our age, philosophy in the proper sense has a special relationship to theology, in particular to the central questions of faith, as is shown by the intense reflections of leading theologians throughout the twentieth century. Today, in accordance with the radically altered situation in culture and science, it appears more prudent to emphasize the model of partnership and proleptic significance.

\section{The Unity Model and Phenomenological Realism}

Realist phenomenology emerged as a reaction to the insufficient and often misleading formulations of Husserlian phenomenology with respect to the exact nature and relationship of the two dimensions of reality, mind and world. For Husserl, mind is centrally the transcendental ego, that is, the ego postulated by empirical experiences; the world is an aspect or dimension of this ego. This position is called transcendental idealism by Husserl. This idealism, however, cannot properly answer the question of the being of the mind or the ego, as was recognized and formulated for the first time by Max Scheler in an influential way. ${ }^{15}$

The two main focusses of realist phenomenology are the source of all essences, that is God, and the corresponding essence of human persons. These centers form a latent whole in realist phenomenology; whenever we speak of God in this perspective, we speak of human personhood as well, because the human and the divine are integrated by the common realm of personhood. However, human personhood is finite and divine personhood is infinite. Nonetheless, precisely this relation between finite and infinite personhood creates the core of reality as conceived by realist phenomenology. This core, however, is viewed not in 
itself but rather in the perspective of pure perfections, that is to say, through perfections which are predicated univocally of God and the world. While focusing on the community of pure or simple perfections, realist phenomenology emphasizes the infinite difference between divine and human personhood. However, to emphasize such a difference is to emphasize the ultimately unique kind of relationship between the infinite and the finite, a relationship traditionally described by the notion of the analogy of being.

Let me introduce here an expression, 'phenomenological realism' as an alternative to realist phenomenology. Realist phenomenology is an analytical understanding of the phenomena with a very strong emphasis on their individual character and, to some extent, their specific connections to one another. Necessarily, such an emphasis goes hand in hand with an understanding of reality which considers the substance more important than the relation. However, relations are also very important and it is especially the overall relational character of reality as such that is more fundamental than any specific or individual moment belonging to any layer of reality as a whole. It appears to be a change of emphasis that I stress the notion of reality as a whole in its entangled character. However, this understanding of reality leads us to a different understanding of the role of the subject of this reality as well, inasmuch as the subject is part and parcel - or even the par excellence expression - of the entangled character of reality. This latter understanding of reality can be described in the form I term phenomenological realism.

Phenomenological realism is realism in an organic way: in the way in which realist phenomenology needs to conceive the community of divine and human personhood. In this sense, phenomenological realism can be termed entangled realism. This realism is not interested in the first place in the specific features of reality but in reality as a whole with its overall structures of synthesis. Phenomenological or entangled realism asks the question of the origin and nature of what is real in our world and mind; and while realist phenomenology points out the aspectual nature of everyday reality, phenomenological realism stresses the importance of the ultimate character of what is real. 
Husserl famously criticized the expression of 'transcendental realism.' ${ }^{36}$ Phenomenological realism, however, is about the phenomenological reality of the intentional; and the question here concerns precisely the nature of that realness of phenomenological reality, a realness which is 'entangled, that is, correlational. ${ }^{17}$ Just as in realist phenomenology, in phenomenological realism the center is described by the relationship between human and divine personhood. In a modified way, however, phenomenological realism attempts to conceive reality as at the same time fulfilled and open; it is open as human personhood shows openness to divine personhood, and divine personhood as a 'pure act' is necessarily infinite personhood. In personhood as such, we find the feature of selftranscendence, openness, or disclosure; and as ultimately real, personhood appears here as a reality deeply entangled with divine personhood.

Accordingly, 'reality' in phenomenological realism is open reality which shows a certain development throughout history. Phenomenological realism is aware of the role of historical change and the significance of the historical trajectory of our personhood and various notions of personhood. Similarly, the notion of reality changes throughout history as shown for instance if we compare the Greek notion of phusis and our contemporary notion of 'physical reality.' Thus it is a paramount task of phenomenological realism to show the main phases and direction of these changes; to show that reality is a process of stemming from, and culminating in, God's ultimate reality. Reality is not dissolved thereby in relativism but displays a network of relations, structures, and their characteristic and meaningful alterations.

Phenomenological realism, however, adds an important dimension to the earlier notions of reality: it considers reality not only in its present

16 Cf. Cartesian meditations, Hua I, p. 63, 121; in the 1960 English translation p. 24, 89.

17 When I apply the adverb 'entangled' here I am aware of the phenomenon of entanglement in quantum experiments, a phenomenon which is not yet understood well enough to build on it a metaphysical corollary. Yet entanglement in the sense of correlation is crucial in the proper understanding of reality in phenomenological realism and this importance may be reflected in the surprising phenomena of quantum entanglement as shown for instance recently by The Big Bell Test (see http://thebigbelltest.org/\#/home?l=EN ). 
situation as the process of the disintegration of an earlier form but at the same time as already containing the germs of an emerging new form of reality and its understanding. This proleptic feature of phenomenological realism is to some extent characteristic of other works of a similar sort, such as Przywara's notion of being as universal rhythm; or Heidegger's notion of the dynamic character of being or Seyn (often translated as Be-ing). In phenomenological or organic realism, a systematic model of proleptic significance can be realized as an expression of the openness of human thinking to newness realized in the future. ${ }^{18}$

\section{The Work of Josef Seifert}

Josef Seifert is the most important representative of realist phenomenology; it is almost impossible to do justice to the immense importance of his work in just one section of a general paper. Still I wish to contextualize his thought in the present outline. Seifert was a disciple of Dietrich von Hildebrand and considers his mentor one of the most important figures in the history of philosophy. It is especially due to the theory of values of Hildebrand that Seifert attributes to this thinker such an important role in the history of thought. On the other hand, Hildebrand's engaged Catholicism has been exemplary for Seifert; in Seifert's philosophy of values, the Catholic notion of reality as a realm of a hierarchy of essences plays an important role. The ultimate focus of values is personhood: the dignity and values of human persons and the infinite dignity of a personal God which he holds to be accessible to human reason, not only to faith; the notion of person as developed throughout the centuries culminates in this philosophy in the notion of a human person as intrinsically related to the divine personhood.

If we want to understand the expression of 'realist phenomenology', we need to consider both terms in a thoroughgoing way. Seifertian thought is phenomenological, because it emphasizes the role of essences or values as directly given to our intuition. It is a phenomenological philosophy

18 Cf. B. M. Mezei, Radical Revelation: A Philosophical Approach, New York 2017 (forthcoming). 
also because the individual essences given in our intuition form a hierarchy, an integral and meaningful structure; on the top of this hierarchy there is the divine essence as the perfect fulfillment and the origin of all values. There is thus an intuition of the divine essence, although a finite being cannot fully conceive that essence. The intuitive knowledge of the irreducible divine essence is the central moment of Seifert's defense of the ontological proof for the existence of God; and it is similarly central in his personalistic interpretation of the five ways of Thomas Aquinas and the specific personalistic proofs of God's existence. ${ }^{19}$ Divine personhood becomes accessible in an indirect way for human beings: not only in positive divine revelation and in the doctrines of the church, or in the life of paramount personalities, such as great saints and exceptionally wise people, but also in the 'mirror of the world' that allows us to intuit the essence of eternity: the first uncaused cause and the necessary existence of God in the intelligible mirror of the chains of finite causes and contingent existents, or again in our moral and intellectual experiences and intuitions which disclose to us the supreme and infinite divine reality of personal pure perfections. ${ }^{20}$

Seifertian thought nevertheless is termed realist phenomenology referring to the realism of ancient but also of specifically Christian and Catholic philosophy. Seifert considers especially the Augustinian form of realism significant. In this conception of reality, the unity of being is understood along the lines of an analogy between the creator and the created, the model and its replica. Thus Seifert's realism considers divine being as the principal form of reality entirely distinct from, and transcendent to, the world, yet cognizable from the world and the human person and united with the world in many ways including analogy as an authentic form of metaphysical similarity: the 'pure perfections' whose ratio formalis exists both in the world and, infinitely more properly, in God. The created world, and especially finite human persons are not related to an

19 J. Seifert, Erkenntnis des Vollkommenen. Wege der Vernunft zu Gott, Bonn 2010.

20 Cf. J. Seifert, Essere e persona. Verso una fondazione fenomenologica di una metafisica classica e personalistica, Milano 1989. 
empty transcendence as a wholly unknown and unknowable ' $\mathrm{X}$, but bre truly similar to God and allow us to perceive in their mirror the archetypical personal perfections of God. This realism may also be termed value realism, since it is the realm of values which constitutes the cohesive structure or, in a sense even more than reality and intelligibility, the most intimate dimension of beings.

Seifertian phenomenology, thus, has two important features: First, reality is fundamentally divine; in its supreme unity it contains all pure perfections in which created reality takes part or which it exemplifies in a finite way. Second, human personhood stands in an intrinsic relationship to divine personhood and expresses divine reality in the highest level possible for a finite being. In other words, realist phenomenology is realist personalism, or to put it in a simpler way, personalism in a simple sense.

The most important aspect of Seifertian thought is his understanding of reality as integral being. His Augustinian ontology differs from a form of realism in which the notion of analogy is based on nearly incomparable natures of the finite and the infinite. Realist thought, in most of its contemporary forms, suggests the primacy of external reality as given to the senses; empirical reality is the touchstone of our knowledge of the real and the unreal, and some form of verificationism is applied as the criterion of this difference. Seifertian realism is different from a sheer external realism of the physical universe and emphasizes the primacy of personal being. Through his further development of the metaphysics of pure perfections, not only the most abstract transcendental of traditional philosophy, but also specifically personal perfections point to the absolute perfections of God. Thus he emphasizes the unity of being: a more intimate and profound relationship of the finite and the infinite being, the finite and the infinite persons, who possesses many of the same perfections, albeit man in a finite, God in an infinite form.

In the above description, I have emphasized those aspects of realist phenomenology which are close to phenomenological or entangled realism. However, Seifert's thought never gets very close to entangled realism given his analytical emphases. Yet, in my view, realist phenomenology 
cannot be properly assessed without the grasp of the integral understanding of being. It is not only the pure perfections that create an integral connection between various layers of being but rather being itself in its entangled or organic characteristic. In the Platonic-Augustinian tradition, the integral conception of being is expressed in the universal hierarchy of essences, or in the intimate relationship between divine personhood and human persons. In contradistinction to a more structured understanding of analogy or an externalist conception of objectivity, the Augustinian view of integral being - which nevertheless reflects the facts of fallen nature - offers a unified conception of reality. Reality, thus, originates in the ultimate reality of integral being. Logically, realist phenomenology is dependent on such an integral understanding of reality, that is, on phenomenological realism.

If we consider the models I outlined above, it seems that some of them fit in with Seifertian thought. His thought emphasizes the doctrinal supremacy of theology yet also the supremacy of philosophy in fundamental theological questions (model 2); it considers philosophy as fulfilling theology in important ways, although, obviously, not entering dogmatic theology properly speaking (model 3). The latter is the fulfillment of any philosophy; yet Seifert's philosophy fulfills fundamental theology in a way which leads beyond the traditional framework of theological introduction: Seifertian theological introduction has a spiritual dimension essential to Catholic morality in his understanding. Yet this correlation belongs to a rational partnership between theology and philosophy, which keeps the dignity of both factors (model 4). Finally, Seifertian thought may be a challenge for some understandings of theological introduction, a challenge calling for appropriate theological answers (model 5). Thus models 2 to 5 are exemplified in Seifertian thought, a fact which shows the integral character of his philosophy.

What about the model of proleptic significance? The immensity of the work of Josef Seifert may be a hindrance to an accurate answer to this question. In general, there are two basic types of philosophy: the one summarizes past results and even revises them; the other grasps the entire context of a tradition and offers a new interpretation of the whole with 
respect to a new form of thought. Josef Seifert's work may belong to the first type yet it shows features of the second type as well.

\section{Consequences and Tasks}

While our contemporary culture favors philosophical specialization, scientism, skepticism or even atheism, philosophers are well advised to be cautious to embrace such views without proper research. It is the task of philosophy to understand properly the historical shift of its own self-understanding from universal knowledge to specific analysis, from philosophical dialectics to logical positivism, or from a theologically interested discipline to the proponent of atheism. Not to see this history of various positions as belonging to a whole would be reducing philosophy to one of its aspects. Secondly, it is crucially important to understand the limits of philosophical reflection, that is, its fundamental heteronomy. Thirdly, it is equally important to recognize the importance of philosophy in understanding heteronomy of human knowledge in the general sense. Fourthly, just on the basis of this heteronomy, philosophy is capable of reaching a certain insight into the reality and nature of genuine autonomy.

With respect to Catholicism, the following appears to be important. The fulfillment of the tasks of philosophy in our day makes it possible and even necessary to rethink the traditional tenets of Catholic Christianity, tenets not only philosophical but also theological in their contents. I call this aspect of philosophy philosophical Catholicism. ${ }^{21}$

${ }^{21}$ I my forthcoming Radical Revelation, the final chapter entitled The Catholicity of Revelation attempts to explain the notion of a philosophical Catholicism based on historical Catholicism yet offering an interpretation instrumental to a philosophical renewal I am delineating in the present paper as well. Let me emphasize here only this much: Philosophical Catholicism has nothing to do with any kind of sectarianism or dogmatism. Rather, philosophical Catholicism aims at the proper understanding and further development of the uniquely rich philosophical traditions connected to historical Catholicism both in the theological and philosophical senses. 
Philosophical Catholicism is to reflect on

- The traditional contents of Catholicism, especially of its doctrinal contents, inasmuch as they are accessible for philosophy, with a special emphasis on the notion of the Trinity;

- The historical change Catholicism has gone through with respect to society, culture, the sciences, and philosophy itself;

- The most acute moral and doctrinal problems of current scientific research from a Catholic perspective;

- The historical perspective in which Catholicism is to accomplish its mission;

- Its proper nature with respect to Catholicism in the form of the unity of models I proposed above.

The prerequisite of doing philosophy in this sense, however, is the community of philosophers who take their philosophical tasks most seriously; philosophers who give their life for the fulfillment of their philosophical vocation with special respect to the tasks I mentioned above. In such a community, some cooperation can be developed which brings its fruits in the realm of the relationship between philosophy and Catholicism. I believe that it is not only philosophy that leads to failure without the appropriate assistance of Catholicism; especially in our age, but in a general sense as well, Catholicism needs philosophy for the fulfillment of its historic vocation in the realms of culture, society, and the sciences. The task of the third millennium of Christianity cannot be the mere survival, as it were, of the age of secularization; it is rather to understand secularization as a challenge which helps us to transcend the earlier horizon of thinking and prepare, with all our means, the age of a new and overarching synthesis, the cultural synthesis of the third millennium. Philosophy of religion, phenomenological or other, possesses a significance inasmuch as it proves to be instrumental to fulfilling the historical task of such a new synthesis. 


\section{Bibliography}

Benedict XIV, Pope, Apostolic Journey Of His Holiness Benedict XVI to München, Altötting and Regensburg (September 9-14, 2006), http://www.vatican.va/holy_father/benedict_xvi/speeches/2006/september/documents/hf_ben-xvi_spe_20060912_ university-regensburg_en.html.

Clement of Alexandria, Stromata, in: The Ante-Nicene Fathers, eds. A. Roberts, J. Donaldson, vol. 2, New York 1913, p. 299-569.

Dietrich von Hildebrands Kampfgegen den Nationalsozialismus, Hrsg. J. Seifert, Heidelberg 1998.

Hessen J., Religionsphilosophie, Vols 1-2, München-Basel 1948.

Husserl E., Cartesian Meditations. An Introduction to Phenomenology, transl. D. Cairns, The Hague-Boston-London 1960.

Husserl E., Cartesianische Meditationen und Pariser Vorträge, Hrsg. S. Strasser, Haag 1950 (Hua I).

John Paul II, Pope, Encyclical Letter FIDES ET RATIO of the Supreme Pontiff John Paul II to the Bishops of the Catholic Church on the Relationship between Faith and Reason, Rome 1998, http://www.vatican.va/holy_father/john_paul_ii/encyclicals/documents/ hf_jp-ii_enc_15101998_fides-et-ratio_en.html.

Liberatore, Matthaeus, Institutiones philosophicae, vol. 1-2, Romae 1857.

Mezei B. M., Demythologizing Christian Philosophy: An Outline, "Logos i Ethos" 2013 nr 2 (35), p. 109-146.

Mezei B. M., Radical Revelation: A Philosophical Approach, New York (forthcoming in 2017).

Mezei B. M., Religion and Revelation after Auschwitz, New York 2013.

Plato, The Complete Works, ed. J. M. Cooper, Indianapolis-Cambridge 1997.

Scheler M., Vom Ewigen im Menschen, Berlin 1933.

Seifert J., Back to Things in Themselves. A Phenomenological Foundation for Classical Realism, London-Boston 1987.

Seifert J., Berührung der Kulturen. Die Rolle der realistischen Phänomenologie im Dialog zwischen Religionen und Zivilisationen, Rabat 2004.

Seifert J., Christian Philosophy and Free Will, introduced by J. Finnis, South Bend (forthcoming in 2017). 
Seifert J., Dietrich von Hildebrands philosophische Entdeckung der 'Wertantwort' und die Grundlegung der Ethik. In Memoriam Dietrich von Hildebrand 1889-1989, "Aletheia" 5 (1992); http://www.iap.li/oldversion/site/research/Aletheia/Aletheia_V/hilds.doc. Seifert J., Discours des Méthodes. The Methods of Philosophy and Realist Phenomenology, Frankfurt-Paris-New Brunswick 2008.

Seifert J., Erkenntnis des Vollkommenen. Wege der Vernunft zu Gott, Bonn 2010.

Seifert J., Erkenntnis objektiver Wahrheit, Salzburg-München 1972.

Seifert J., Essere e persona. Verso una fondazione fenomenologica di una metafisica classica e personalistica, Milano 1989.

Seifert J., Gott als Gottesbeweis. Eine phänomenologische Neubegründung des ontologischen Arguments. Heidelberg 1996 (2000).

Seifert J., Überwindung des Skandals der reinen Vernunft. Die Widerspruchsfreiheit der Wirklichkeit - trotz Kant, Freiburg 2001.

Seifert J., Das Wesen der Wahrheit und die Person. De veritate - Über die Wahrheit, Bd. 1-2, Frankfurt- Paris-Ebikon-Lancaster-New Brunswick 2009.

Seifert J., What is Life? On the Originality, Irreducibility and Value of Life, Amsterdam 1997. Taylor Ch., A Secular Age, Cambridge-Massachusetts-London 2007.

\section{Abstract \\ Realist Phenomenology and Philosophy of Religion. A Critical Reflection}

The aim of the present paper is to show that Catholicism is not a closed segment of contemporary philosophy but rather a rich source of traditions and developments which are alive even today and can help to understand our philosophical situation and contribute to a renaissance of influential philosophy in our culture. In more detail, I shall focus on the importance of Catholic philosophy in its history and present day situation as part and parcel of our general philosophical traditions. I offer a list of models describing the possible relationships between Catholicism and philosophy. I identify the unity model as a model connected to phenomenological realism; and I will detail the important contribution of Josef Seifert to such a phenomenological realism. Phenomenological realism as 
an expression is offered here as a modification of realist phenomenology, a modification based on the recognition of what I term the entangled nature of reality.

\section{Keywords}

Phenomenological realism, realist phenomenology, faith and reason, Catholicism and philosophy, entanglement, Josef Seifert 